\title{
Alcohol Withdrawal Syndrome: a Review
}

Iustin Moroi', Mihaela Adela lancu², Alexandra Ana Maria Stanescu², Anca Pantea Stoian², Razvan Hainarosie, ${ }^{2,3}$, Bogdan Socea ${ }^{2,4}$, Dragos Marcu, 2,5, Dan Arsenie Spinu2,5, Ovidiu Gabriel Bratu2,5,6, Camelia Diaconu ${ }^{1,2}$

\begin{abstract}
Alcoholism is a common condition and frequently clinicians are forced to confront its complications in general hospital settings. There are an estimated 3 million alcohol-dependent people in Romania alone, from which a significant number suffers episodes of withdrawal severe enough to require pharmacologic treatment. Alcohol withdrawal syndrome is a clinical diagnosis, with symptoms that range from minor (anxiety/palpitations) to severe (delirium tremens/hallucinations). Benzodiazepines have the best evidence in treating this disease. A symptom-triggered therapy approach is favored using a validated tool, such as CIWA-Ar (Clinical Institute Withdrawal Assessment for Alcohol Scale, Revised), for shorter periods of hospitalization and for using lower doses of sedatives.
\end{abstract}

Keywords: alcohol withdrawal syndrome, alcoholism, benzodiazepines

\section{Rezumat}

Alcoolismul este o afecțiune comună și adesea clinicienii se confruntă cu complicațiile sale în condiții de spital. Există aproximativ 3 milioane de persoane dependente de alcool numai în România, dintre care un număr semnificativ suferă episoade de abstinență suficient de severe pentru a necesita tratament farmacologic. Sindromul de abstinență la alcool este un diagnostic clinic, cu simptome care variază de la minore (anxietate / palpitații) la severe (delirium tremens/ halucinații). Benzodiazepinele au cele mai bune dovezi în tratarea acestei boli. 0 abordare terapeutică ghidată de simptome este favorizată utilizând un instrument validat, cum ar fi CIWA-Ar (Clinical Institute Withdrawal Assessment for Alcohol Scale, Revised), pentru perioade mai scurte de spitalizare și pentru utilizarea unor doze mai mici de sedative.

Cuvinte-cheie: sindromul de abstinență la alcool, alcoolism, benzodiazepine

\section{INTRODUCTION}

Alcoholism is a common condition and frequently clinicians are forced to confront its complications in general hospital settings. Within each country, there is an excellent correlation between the level of alcohol consumption and the prevalence of alcohol-related harm. In fact, the consumption in Europe is 10.9 liters of pure

\footnotetext{
${ }^{1}$ Clinical Emergency Hospital of Bucharest, Bucharest, Romania

2 "Carol Davila" University of Medicine and Pharmacy, Bucharest, Romania

3 "Prof. Dr. D. Hociota" Institute of Phonoaudiology and

Functional ENT Surgery, Bucharest, Romania

${ }^{4}$ "St. Pantelimon" Emergency Hospital, Bucharest, Romania

${ }^{5}$ Clinic of Urology, Central Military Hospital, Bucharest, Romania

${ }^{6}$ Academy of Romanian Scientists, Bucharest, Romania
}

alcohol per person per year ${ }^{1}$. There are an estimated 3 million alcohol-dependent people in Romania alone, with episodes of withdrawal severe enough to require pharmacologic treatment ${ }^{1}$.

Studies have shown that patients with sudden cessation of chronic and sustained alcohol intake develop a more severe alcohol withdrawal syndrome (AWS) than the casual drinkers, who do not have constant high

\section{Corresponding author.}

lustin Moroi, Clinical Emergency Hospital of Bucharest, $8^{\text {th }}$ Calea Floreasca, Bucharest, Romania.

E-mail: moroi.iustin@yahoo.com 
blood concentrations of alcohol necessary to develop tolerance. It is still unclear why some people develop more severe withdrawal syndromes than others, but genetics may play a role.

\section{PATHOPHYSIOLOGY}

Alcohol is a central nervous system (CNS) inhibitor, concurrently enhancing the inhibitory tone (through gamma-aminobutyric acid activity) and inhibiting the excitatory tone (through the modulation of excitatory amino acids activity). Chronic intake of alcohol leads to a homeostasis kept in place by its constant presence, with sudden cessation often resulting in over-activity of the CNS.

Gamma-aminobutyric acid (GABA) is the major inhibitory neurotransmitter in the CNS and its receptor complex has highly specific binding sites for ethanol. Chronic and sustained alcohol usage induces insensitivity to GABA in such a way that more inhibitor is required to maintain a decreased CNS excitability. CNS adapts by down-regulating the GABA receptors, thus increasing the requirement of larger quantities of ethanol for achieving the same euphoric effect.

Glutamate is one of the major excitatory aminoacids. Its binding to NMDA (N-methyl-D-aspartate) receptor causes neuronal excitation. Because ethanol inhibits glutamate-induced excitation, CNS adapts by up-regulating NMDA receptors and increase the production of glutamate, in an attempt to maintain a normal state of awakening.

Because of its effects of inhibiting the excitatory state of the CNS and enhancing the inhibitory effect of GABA, sudden cessation of alcohol in the chronic user often leaves CNS glutamate excitation unopposed, expressed in mild autonomic over-activity, such as tachycardia, sweating or more severe symptoms such as delirium tremens and withdrawal seizures ${ }^{2}$.

\section{PAWSS SCORE (Prediction of Alcohol Withdrawal Severity Score)}

A tool for predicting the risk for alcohol withdrawal is the PAWSS Score (Table 1). This instrument is intended as a screening tool. The maximum number of points is 10. A greater number of points shows a higher risk for developing AWS. A value below 4 shows a low risk for developing AWS, while a value above sets a moderate risk.

\section{COMPLICATIONS OF ALCOHOL WITHDRAWAL}

A diagnosis of AWS is made when:

- a clear evidence of recent cessation/reduction of alcohol intake after heavy and prolonged use is confirmed;

- the patients' symptoms are not accounted for by another medical or behavioral disorder.

Diagnosis requires the history of the amount and frequency of alcohol intake, the temporal relation between reduction of intake and the onset of symptoms that may resemble a withdrawal state. AWS can occur as early as 6 hours after alcohol cessation, peaks after 2-3 days and can persist up to 7 days after alcohol cessation. If the onset of withdrawal-like symptoms is after more than 14 days of complete cessation of alcohol, the diagnosis of AWS becomes unsustainable. Symptoms range from minor to severe ${ }^{4}$. Minor wi-

Table 1. Prediction of Alcohol Withdrawal Severity Score (PAWSS) $^{3}$

\begin{tabular}{|c|c|}
\hline Part A: Threshold Criteria & Score (1 point) \\
\hline $\begin{array}{l}\text { 1. Have you consumed any amount of alcohol } \\
\text { (i.e. been drinking) within the last } 30 \text { days? }\end{array}$ & \\
\hline $\begin{array}{l}\text { OR did the patient have a positive blood alcohol } \\
\text { level (BAL) on admission? }\end{array}$ & \\
\hline $\begin{array}{l}\text { If the answer is Yes to either question, proceed } \\
\text { with the test: }\end{array}$ & \\
\hline Part B: Patient Interview & \\
\hline $\begin{array}{l}\text { 2. Have you ever experienced previous episodes } \\
\text { of alcohol withdrawal? }\end{array}$ & \\
\hline $\begin{array}{l}\text { 3. Have you ever experienced an alcohol wi- } \\
\text { thdrawal seizure? }\end{array}$ & \\
\hline $\begin{array}{l}\text { 4. Have you ever experienced delirium tremens } \\
\text { or DT's? }\end{array}$ & \\
\hline $\begin{array}{l}\text { 5. Have you ever undergone alcohol rehabi- } \\
\text { litation treatment? (i.e., inpatient, outpatient } \\
\text { treatment programs or alcoholic anonymous } \\
\text { attendance) }\end{array}$ & \\
\hline 6. Have you ever experienced blackouts? & \\
\hline $\begin{array}{l}\text { 7. Have you combined alcohol with other } \\
\text { "downers" like benzodiazepines or barbiturates } \\
\text { during the last } 90 \text { days? }\end{array}$ & \\
\hline $\begin{array}{l}\text { 8. Have you combined alcohol with any other } \\
\text { substance of abuse during the } 90 \text { days? }\end{array}$ & \\
\hline Part C: Clinical Evidence & \\
\hline $\begin{array}{l}\text { 9. Was the patient's blood alcohol level (BAL) on } \\
\text { presentation }>200 \mathrm{mg} / \mathrm{dL} \text { ? }\end{array}$ & \\
\hline $\begin{array}{l}\text { 10. Is there evidence of increased autonomic } \\
\text { activity? (i.e., } \mathrm{HR}>120 \mathrm{bpm} \text {, tremor, sweating, } \\
\text { agitation, nausea) }\end{array}$ & \\
\hline TOTAL SCORE & \\
\hline
\end{tabular}


Table 2. Minor alcohol withdrawal signs and symptoms

\begin{tabular}{|l|l|}
\hline Signs & Symptoms \\
\hline Elevated blood pressure & Anxiety \\
\hline Elevated body temperature & Hallucinations \\
\hline Dilated pupils & Illusions \\
\hline Tachycardia $>100 \mathrm{bpm}$ & Insomnia \\
\hline Sweating & Irritability \\
\hline
\end{tabular}

thdrawal signs and symptoms are due to CNS hyperactivity (Table 2).

If withdrawal does not progress, the symptoms resolve within 24 to 48 hours and can be managed in ambulatory settings.

Moderate to severe withdrawal usually begins 48$72 \mathrm{~h}$ after the last drink and can last up to 14 days. Syndromes specific for non-minor withdrawal are alcoholic hallucinosis, alcohol withdrawal seizure and delirium tremens. Severe alcohol withdrawal is often associated with fluid and electrolyte status abnormalities. Due to diaphoresis, hyperthermia and decreased oral intake, many patients are hypovolemic. Hypomagnesemia may predispose to seizures and dysrhythmias ${ }^{5}$.

Alcoholic hallucinosis - visual/tactile/auditory hallucinations that appear in a well-oriented patient with stable vitals. In most cases lasts between $24 \mathrm{~h}$ and 6 days $^{6}$.

Alcohol withdrawal seizure - usually generalized tonico-clonic seizures. May begin within 6-48 h after last drink. It presents a high risk of progression towards delirium tremens.

Delirium tremens (DT) - is a specific type of delirium in patients suffering from alcohol withdrawal, consisting in altered sensorium with disorientation, perceptual abnormalities (illusions and hallucinations) and psychomotor agitation with altered sleep wake-cycle. It begins after 48-72 $\mathrm{h}$ after the last drink and may last up to 14 days. Studies show a mortality between 5 and 10 percent, hence early recognition is important. Death usually occurs due to arrhythmia or associated comorbid illness such as pneumonia ${ }^{7}$.

\section{CLINICAL INSTITUTE WITHDRAWAL ASSESSMENT FOR ALCOHOL SCALE, REVISED (CIWA-AR)}

After the clinical diagnosis of alcohol withdrawal syndrome has been established, the management is directed at alleviating symptoms and identifying and correcting metabolic derangements. Supportive care, including nutritional supplementation and frequent clinical reassessment, is of crucial importance.

An instrument to objectively measure the severity of alcohol withdrawal is the CIWA-Ar scale (Clinical Institute Withdrawal Assessment - Alcohol Revised). It is not useful in differentiating between DT and delirium caused by other medical illnesses ${ }^{8}$. The scale includes 10 common signs and symptoms of alcohol withdrawal, with notable exceptions of pulse rate and blood pressure. Scores of 0-9 indicate absent to minimal withdrawal, 10-19 indicate mild to moderate withdrawal (increased autonomic arousal) and scores greater than 20 or more indicate severe withdrawal, with a high risk of developing DT. The score can be used to monitor the severity of withdrawal and in titrating pharmacotherapy.

Observations should be carried out every 2 hours and consist of:

- Measuring blood pressure.

- Measuring pulse.

- Measuring respiratory rate [if below 10 breaths per minute - call emergency team].

- Applying CIWA-Ar scale.

The descriptions of each withdrawal syndrome is rated and then added for a final score.

CIWA-Ar maximum score is 67 . In the first 24 hours, the score should be re-evaluated every 2 hours; if the score is between 0 to 9 or the patient is asleep, no treatment is needed, if it is above 8 , pharmacologic treatment is needed.

\section{MANAGEMENT OF ACUTE ALCOHOL WITHDRAWAL SYNDROME}

Prior to treatment, patients should be investigated clinically and paraclinically, regarding the degree of possible liver alterations or other comorbidities ${ }^{9-14}$. Patients require non-pharmacologic, as well as pharmacologic treatment. Patients suffering from alcohol withdrawal are best treated in a quiet room, where minimal external stimulation can occur. All patients with moderate to severe AWS should have immediate IV access for rapid administration of drugs and fluids. Intramuscular administration should be avoided because of variable drug absorption. Adequate sedation is necessary in order to maintain a calm, but alert patient. In some cases, physical restraints are used for prevention of injuries due to agitation. Fluid and electrolyte imbalances must be promptly corrected. Vitamin B supplementation helps to prevent Wernicke's encephalopathy (WE). In the first days, treatment should be administered intra- 


\section{Table 3. Clinical Institute Withdrawal Assessment for Alcohol - Revised (CIWA-Ar) scale ${ }^{8}$}

\begin{tabular}{|c|c|}
\hline $\begin{array}{l}\text { Nausea and Vomiting: } \\
\text { Ask "Do you feel sick to your stomach? Have you vomited?" } \\
\text { Observation: } \\
0 \text { no nausea with no vomiting } \\
1 \text { mild nausea with no vomiting } \\
2 \\
3 \\
4 \text { intermittent nausea with dry heaves } \\
5 \\
6 \\
7 \text { constant nausea, frequent dry heaves and vomiting }\end{array}$ & $\begin{array}{l}\text { Tactile (touch) Disturbances: } \\
\text { Ask "Have you any itching, pins and needles sensations, any burning, any } \\
\text { numbness, or do you feel bugs crawling on or under your skin?" Observati- } \\
\text { on: } \\
0 \text { none } \\
1 \text { very mild itching, pins and needles, burning or numbness } \\
2 \text { mild itching, pins and needles, burning or numbness } \\
3 \text { moderate itching, pins and needles, burning or numbness } \\
4 \text { moderately severe hallucinations } \\
5 \text { severe hallucinations } \\
6 \text { extremely severe hallucinations } \\
7 \text { continuous hallucinations }\end{array}$ \\
\hline $\begin{array}{l}\text { Tremor: } \\
\text { Arms extended and fingers spread wide apart. } \\
\text { Observation: } \\
0 \text { no tremor } \\
1 \text { not visible, but can be felt fingertip to fingertip } \\
2 \\
3 \\
4 \text { moderate, with patients' arms extended } \\
5 \\
6 \\
7 \text { severe, even with arms not extended }\end{array}$ & $\begin{array}{l}\text { Auditory (hearing) Disturbances: } \\
\text { Ask "Are you more aware of sounds around you? Are they harsh? Do they } \\
\text { frighten you? Are you hearing anything that is disturbing you? Are you hea- } \\
\text { ring things you know are not there?" Observation: } \\
0 \text { not present } \\
1 \text { very mild harshness or ability to frighten } \\
2 \text { mild harshness or ability to frighten } \\
3 \text { moderate harshness or ability to frighten } \\
4 \text { moderately severe hallucinations } \\
5 \text { severe hallucinations } \\
6 \text { extremely severe hallucinations } \\
7 \text { continuous hallucinations }\end{array}$ \\
\hline $\begin{array}{l}\text { Observation: } \\
0 \text { no sweat visible } \\
1 \text { barely perceptible sweating, palms moist } \\
2 \\
3 \\
4 \text { beads of sweat obvious on forehead } \\
5 \\
6 \\
7 \text { drenching sweats } \\
\end{array}$ & $\begin{array}{l}\text { Visual (sight) Disturbances: } \\
\text { Ask "Does the light appear to be too bright? Is it's colour different? Does } \\
\text { it hurt your eyes? Are you seeing anything that's disturbing you? Are you } \\
\text { seeing anything that you know is not there?" } \\
\text { Observation: } \\
0 \text { not present } \\
1 \text { very mild sensitivity } \\
2 \text { mild sensitivity } \\
3 \text { moderate sensitivity } \\
4 \text { moderately severe hallucinations } \\
5 \text { severe hallucinations } \\
6 \text { extremely severe hallucinations } \\
7 \text { continuous hallucinations }\end{array}$ \\
\hline $\begin{array}{l}\text { Anxiety: } \\
\text { Ask "Do you feel nervous?" } \\
\text { Observation: } \\
0 \text { no anxiety, at ease } \\
1 \text { mildly anxious } \\
2 \\
3 \\
4 \text { moderately anxious or guarded, so anxiety is suggested } \\
5 \\
6 \\
7 \text { equivalent to acute panic states as seen in severe delirium or } \\
\text { acute schizophrenic states } \\
\end{array}$ & $\begin{array}{l}\text { Headache, Fullness in Head: } \\
\text { Ask "Does your head feel different? Does it feel like there is a band around } \\
\text { your head? Do not rate for dizziness or lightheadedness. Otherwise, rate } \\
\text { severity. } \\
\text { Observation: } \\
0 \text { not present } \\
1 \text { very mild } \\
2 \text { mild } \\
3 \text { moderate } \\
4 \text { moderately severe } \\
5 \text { severe } \\
6 \text { very severe } \\
7 \text { extremely severe } \\
\end{array}$ \\
\hline $\begin{array}{l}\text { Agitation: } \\
\text { Observation: } \\
0 \text { normal activity } \\
1 \text { somewhat more than normal activity } \\
2 \\
3 \\
4 \text { moderately fidgety and restless } \\
5 \\
6 \\
7 \text { paces back and forth during interview, or thrashes abou }\end{array}$ & $\begin{array}{l}\text { Orientation and Clouding of Sensorium: } \\
\text { Ask „What day is this? Where are you? Who am I?" } \\
0 \text { orientated and can do serial additions } \\
1 \text { cannot do serial additions or is uncertain about date } \\
2 \text { disorientated for date by no more than } 2 \text { calendar days } \\
3 \text { disorientated for date by more than } 2 \text { calendar days } \\
4 \text { disorientated for place or person }\end{array}$ \\
\hline
\end{tabular}


venously, due to impaired gastrointestinal absorption often met in chronic alcohol users. During the early phases of withdrawal, patients are given nothing by mouth, to decrease the risk of aspiration.

The main treatment of AWS is detoxification and consists in gradually tampering the dependence.

Studies are strongly in favor of using benzodiazepines for treating acute AWS, because they undoubtedly reduce the risk of seizures and DT15. Diazepam, lorazepam and chlordiazepoxide are most commonly used. Benzodiazepines enhance the effect of the gammaaminobutyric acid at the GABA receptor, resulting in sedative, hypnotic and anxiolytic effects. Chlordiazepoxide and diazepam are the agents of choice, but in the presence of co-morbidities, oxazepam and lorazepam are recommended, due to their shorter half-life, that prevents prolonged effects if over-sedation occurs. Patients with impaired hepatic function (advanced cirrhosis or acute alcoholic hepatitis) are best treated with lorazepam or oxazepam. The equivalency of benzodiazepine doses (approximate) are as following: diazepam $10 \mathrm{mg}$ = chlordiazepoxide $25 \mathrm{mg}=$ lorazepam $1 \mathrm{mg}^{16}$.

Anticonvulsants have not been proven to be better than benzodiazepines, but may be considered in mild withdrawal states, because of lower sedation and lower chances of abuse potential.

\section{TREATMENT REGIMENS USED IN ALCOHOL WITHDRAWAL STATES}

The fixed-dose regimen consists in giving benzodiazepines (dose based upon the severity of the withdrawal and time since the last drink) at fixed intervals. Because frequent reassessment of the clinical status of the $\mathrm{pa}^{-}$ tient is not needed, this regimen is best suited for minimally symptomatic patients in out-patient settings ${ }^{16}$.

The loading dose regimen consists in treating the patient with $20 \mathrm{mg}$ of diazepam per os every $2 \mathrm{~h}$, but before each administration, the clinical condition and the withdrawal severity using CIWA-Ar score must be checked. This regimen has been shown to reduce the total dose of administered benzodiazepines and the duration of withdrawal symptoms ${ }^{17}$.

Symptom-triggered treatment (STT) requires close monitoring of symptoms and treating the in-patient with drugs only when CIWA-Ar ratings are 8 or more. Frequent re-evaluation of the clinical status is needed. It is useful in patients who have never had complicated withdrawals. Multiple randomized and observational studies support this regimen because it achieves equi- valent clinical endpoints while requiring lower total doses of sedatives and shorter periods of hospitalization $^{18}$.

Symptom-monitored loading regimen: In the presence of acute medical illness or a past history of severe withdrawals, a single loading dose of $20 \mathrm{mg}$ diazepam should preferably be given immediately. Further doses of diazepam should be given orally every $2 \mathrm{~h}$ until CIWA-Ar scores are less than ten. This strategy combines the principles of symptom-triggered treatment strategy while also taking into account the past history of severe withdrawals ${ }^{17}$.

\section{MANAGEMENT OF MINOR ALCOHOL WITHDRAWAL SYNDROME}

Minor cases of withdrawal may not need pharmacologic treatment in most cases, and often the supportive care in a calm and quiet environment over a $36 \mathrm{~h}$ period is enough ${ }^{16}$. An acute medical illness or a history of severe episodes of alcohol withdrawal justify the use of a single dose of $20 \mathrm{mg}$ of diazepam and further monitoring ${ }^{19}$. In the absence of these risk factors, out-patient treatment is possible.

Pharmacotherapy is started if the patient presents signs of CNS hyperexcitability, like increased systolic blood pressure (above $150 \mathrm{mmHg}$ ), increased diastolic blood pressure (above $90 \mathrm{mmHg}$ ), tachycardia (above 100/min), fever (body temperature above 37.7 Celsius degrees), agitation or insomnia ${ }^{4}$.

\section{MANAGEMENT OF MODERATE TO SEVERE ALCOHOL WITHDRAWAL SYNDROME}

Cases without seizures or DT are best managed using a symptom-monitored loading regimen (treating with benzodiazepines only if CIWA-Ar score is above 9) or with a fixed-dose regimen, where adequate personnel for calculating CIWA-Ar score is not available ${ }^{20}$.

In cases with seizures or DT, a rapid loading regimen is preferred, with frequent boluses of intravenous diazepam, until the patient is calm and sedated, regardless of the CIWA-Ar score ${ }^{21-24}$. Seizure prophylaxis with 2 $\mathrm{mg} I V$ lorazepam is recommended for patients with past history of withdrawal seizure. Lorazepam is more effective than diazepam in preventing seizure recurrence, due to its poor lipid solubility, which does not let brain levels fall rapidly. In such patients, it may still be required do give diazepam doses of at least $20 \mathrm{mg}-$ 
$60 \mathrm{mg}$ in a symptom-monitored regimen ${ }^{25}$. In patients with seizures, a neurological workup is needed to detect alternative cause ${ }^{26-28}$. DT is best treated with the use of IV diazepam administered at frequent intervals, with close monitoring. Treatment begins with an initial dose of $10 \mathrm{mg}$ of diazepam. Further doses of $10 \mathrm{mg}$ are given at approximately 15 minutes interval ${ }^{29-30}$. Once the goal of light somnolence is achieved, the patient can be shifted to a symptom-triggered regimen ${ }^{23,31}$.

The undiluted emulsion is administered at a rate of $1 \mathrm{ml}(5 \mathrm{mg})$ per minute. For patients with liver failure, IV lorazepam is the drug of choice. The goal of sedation is a calm, but alert state. In the elderly, only half the benzodiazepine dose is recommended.

For patients who are difficult to assess using the CIWA-Ar score, a fixed schedule reducing regimen is recommended. This includes patients who are confused, don't speak the native tongue or are unable to communicate effectively.

Inappropriately managed WE is a major contributory cause of death in patients suffering from alcohol withdrawal syndrome and results in permanent brain damage in a great number of survivors. Because the classic triad of signs, consisting in acute confusion, ataxia and ophthalmoplegia, is only seen in $10 \%$ percent of patients, it cannot be used as a basis of diagnosis.
Wernicke's encephalopathy is reversible in the early stages, if a rapid restoration of $\mathrm{B}$ vitamins (in particular thiamine - B1) in CNS is initiated.

All patients undergoing alcohol withdrawal should be treated prophylactically for WE with thiamine 100 mg IV ampoule, three times a day. Every ampoule should be diluted in $50 \mathrm{ml}$ to $100 \mathrm{ml}$ sodium chloride $0.9 \%$ and infused over 30 minutes. Absorption of oral thiamine is limited and not sufficient to treat WE.

\section{CONCLUSIONS}

Chronic alcohol consumption poses many risks on the health status. AWS is associated with risks of complications and should be carefully managed in the clinical practice, by non-pharmacologic measures and pharmacological treatment.

Compliance with ethics requirements:

The authors declare no conflict of interest regarding this article.

The authors declare that all the procedures and experiments of this study respect the ethical standards in the Helsinki Declaration of 1975, as revised in 2008(5), as well as the national law. Informed consent was obtained from all the patients included in the study.

\section{References}

1. WHO. GLOBAL STATUS REPORT on noncommunicable diseases 2014. WHO Library Cataloguing-in-Publication Data; 2014.

2. Koob GF. The neurobiology of addiction: A neuroadaptational view relevant for diagnosis. Addiction. 2006;101(Supp 1):2330.

3. Maldonado JR, Sher Y, Ashouri JF, Hills-Evans K, Swendsen H, Lolak S, Miller AC. The "Prediction of Alcohol Withdrawal Severity Scale" (PAWSS): systematic literature review and pilot study of a new scale for the prediction of complicated alcohol withdrawal syndrome. Alcohol, 2014, 48(4): 375-390.

4. Miller NS, Gold MS. Management of withdrawal syndromes and relapse prevention in drug and alcohol dependence. Am Fam Physician. 1998;58:139-46.

5. Tovar R. Diagnosis and treatment of alcohol withdrawal. J Clin Outcomes Manag. 2011;18:361-70.

6. Victor M, Adams RD. The effect of alcohol on the nervous system. Res Publ Assoc Res Nerv Ment Dis. 1953;32:526.

7. Tavel ME, Davidson W, Batterton TD. A critical analysis of mortality associated with delirium tremens. Review of 39 fatalities in a 9-year period. Am J Med Sci. 1961;242:18.

8. Sullivan JT, Sykora K, Schneiderman J, Naranjo CA, Sellers EM. Assessment of alcohol withdrawal: The revised clinical institute withdrawal assessment for alcohol scale (CIWA-Ar). $\mathrm{Br} J$ Addict. 1989;84:1353-7.

9. Drăghici T, Negreanu L, Bratu OG, Tincu R, Socea B, lancu MA, Stănescu AMA, Diaconu C. Liver abnormalities in patients with heart failure. Archives of the Balkan Medical Union, 2018, 53(1):76-81.

10. Berceanu D, Bucur D, Diaconu C. Type 2 diabetes and liver disease: a frequent and harmful connection. Archives of the Balkan Medical Union, 2016, 51(4):506-511.

11. Bucur D, Berceanu D, Diaconu C. Hemostasis in patients with cirrhosis: a hazardous balance. Archives of the Balkan Medical Union, 2016, 51(4):501-505

12. Diaconu C, Bălăceanu A, Bartoş D. What do liver function tests say about the heart function? Medicina Modernă, 2014, 21(3):145-149.

13. Diaconu C. Evaluarea rezultatelor anormale ale testelor hepatice. Practica Medicală, 2011, VI, 21(1): 49-52.

14. Diaconu C. Evaluarea unui pacient asimptomatic cu valori crescute ale transaminazelor serice. Medicina Modernă 2010, XVII(11):573-575.

15. Kaim SC, Klett CJ, Rothfeld B. Treatment of the acute alcohol withdrawal state: A comparison of four drugs. Am J Psychiatry. 1969;125:1640-6.

16. Amato L, Minozzi S, Davoli M. Efficacy and safety of pharmacological interventions for the treatment of the alcohol withdrawal syndrome. Cochrane Database Syst Rev. 2011;6:CD008537. 
17. Manikant S, Tripathi BM, Chavan BS. Loading dose diazepam therapy for alcohol withdrawal state. Indian J Med Res. 1993; 98:170-3.

18. Saitz R, Mayo-Smith MF, Roberts MS, Redmond HA, Bernard DR, Calkins DR. Individualized treatment for alcohol withdrawal. A randomized double-blind controlled trial. JAMA. 1994;272:51923.

19. Saitz R, O'Malley SS. Pharmacotherapies for alcohol abuse. Withdrawal and treatment. Med Clin North Am. 1997;81:881-907.

20. D'Onofrio G, Rathlev NK, Ulrich AS, Fish SS, Freedland ES. Lorazepam for the prevention of recurrent seizures related to alcohol. N Engl J Med. 1999;340:915-9.

21. Kosten TR, O'Connor PG. Management of drug and alcohol withdrawal. N Engl J Med 2003; 348:1786.

22. DeBellis R, Smith BS, Choi S, Malloy M. Management of delirium tremens. J Intensive Care Med 2005; 20:164.

23. Amato L, Minozzi S, Vecchi S, Davoli M. Benzodiazepines for alcohol withdrawal. Cochrane Database Syst Rev 2010; CD005063

24. Cassidy EM, O'Sullivan I, Bradshaw P, et al. Symptom-triggered benzodiazepine therapy for alcohol withdrawal syndrome in the emergency department: a comparison with the standard fixed dose benzodiazepine regimen. Emerg Med J 2012; 29:802.
25. Devenyi P, Harrison ML. Prevention of alcohol withdrawal seizures with oral diazepam loading. Can Med Assoc J. 1985;132: 798-800

26. Diaconu $C$, Bălăceanu $A$, Moroşan E. Sepsis biomarkers: past, present and future. Farmacia 2015, 63(6):811-815

27. Diaconu C. Midaortic syndrome in a young man. Cor et Vasa 2017;59:e171-e173

28. Diaconu CC, Dediu GN, lancu MA. Drug-induced arterial hypertension, a frequently ignored cause of secondary hypertension: a review. Acta Cardiologica 2018. DOI 10.1080/00015385. 2017.1421445

29. Minozzi S, Amato L, Vecchi S, Davoli M. Anticonvulsants for alcohol withdrawal. Cochrane Database Syst Rev 2010; :CD005064.

30. Hack JB, Hoffmann RS, Nelson LS. Resistant alcohol withdrawal: does an unexpectedly large sedative requirement identify these patients early? J Med Toxicol 2006; 2:55.

31. Socea LI, Visan DC, Barbuceanu SF, Apostol TV, Bratu OG, Socea $B$. The antioxidant activity of some acylhydrazones with dibenzo[a,d][7]annulene moiety. Revista de Chimie, 2018, 5: 2537-5733. 
